\title{
A Non-Pt Electronically Coupled Semiconductor Heterojunction for Enhanced Oxygen Reduction Electrocatalytic Property
}

\author{
Fan $\mathrm{Li}^{+},{ }^{[\mathrm{a}]}$ Yong $\mathrm{Qin}^{+}{ }^{[\mathrm{a}]}$ Aleksei Chalgin ${ }^{+}{ }^{[\mathrm{a}]}$ Xin $\mathrm{Gu}{ }^{[\mathrm{a}]}$ Wenlong Chen, ${ }^{[\mathrm{a}]}$ Yanling Ma, ${ }^{[\mathrm{a}]}$ \\ Qian Xiang, ${ }^{[a]} \mathrm{Yi} \mathrm{Wu}_{r}{ }^{[\mathrm{a}]}$ Fenglei Shi, ${ }^{[\mathrm{a}]}$ Yuan Zong ${ }^{[\mathrm{a}]}$ Peng Tao, ${ }^{[\mathrm{a}]}$ Chengyi Song, ${ }^{[\mathrm{a}]}$ Wen Shang, ${ }^{[\mathrm{a}]}$ \\ Tao Deng, ${ }^{[a, b]}$ Hong Zhu, ${ }^{*[a, c, d]}$ and Jianbo $W^{*[a, b, d]}$
}

\begin{abstract}
Hybrid faceted- $\mathrm{Ag}_{3} \mathrm{PO}_{4} / \mathrm{cube}-\mathrm{Cu}_{2} \mathrm{O}$ composite materials have been fabricated and employed as oxygen reduction electrocatalysts for proton exchange membrane fuel cells (PEMFCs). The charge separation effect via the formation of PN junction has been demonstrated to boost the electrocatalysis toward oxygen reduction reaction. The as-prepared rhombic dodecahedron- $\mathrm{Ag}_{3} \mathrm{PO}_{4} /$ cube- $\mathrm{Cu}_{2} \mathrm{O} / \mathrm{C}$ hybrid catalyst shows a massspecific activity of $109.80 \mathrm{~mA} / \mathrm{mg}_{\mathrm{Ag}}$, which is about 6.4 times that of pure rhombic dodecahedron- $\mathrm{Ag}_{3} \mathrm{PO}_{4} / \mathrm{C}$ catalyst $\left(17.20 \mathrm{~mA} / \mathrm{mg}_{\mathrm{Ag}}\right)$. The density functional theory (DFT) calculation based on the density of states (DOS) further proved the optimal tunable effect, which is in pace with demonstration of electron transfer direction revealed by X-ray photoelectron spectroscopy (XPS) analysis. Our work establishes a theoretical and practical basis for the rational design of newly non-Pt hybrid catalysts, moreover, advances the future efficient application of PEMFCs.
\end{abstract}

\section{Main Text}

Developing cost-effective proton-exchange membrane fuel cells (PEMFCs) plays a key role for a wide variety of clean energy applications. ${ }^{[1-3]}$ The sluggish kinetics of oxygen reduction reaction (ORR) is still one of the most limiting factors. ${ }^{[1,4,5]}$

[a] Dr. F. Li, ${ }^{+} Y$. Qin, ${ }^{+}$Dr. A. Chalgin, ${ }^{+}$Dr. X. Gu, Dr. W. Chen, Dr. Y. Ma, Dr. Q. Xiang, Y. Wu, Dr. F. Shi, Y. Zong, Prof. P. Tao, Prof. C. Song, Prof. W. Shang, Prof. T. Deng, Prof. H. Zhu, Prof. J. Wu

State Key Laboratory of Metal Matrix Composites, School of Materials Science and Engineering, Shanghai Jiao Tong University, 800 Dongchuan Road, Shanghai 200240 (P. R. China)

E-mail: hong.zhu@sjtu.edu.cn jianbowu@sjtu.edu.cn

[b] Prof. T. Deng, Prof. J. Wu

Center of Hydrogen Science, Shanghai Jiao Tong University

[c] Prof. H. Zhu

University of Michigan-Shanghai Jiao Tong University Joint Institute, Shanghai Jiao Tong University

[d] Prof. H. Zhu, Prof. J. Wu

Materials Genome Initiative Center, Shanghai Jiao Tong University

$\left.{ }^{+}{ }^{+}\right]$The authors Fan Li, Yong Qin and Aleksei Chalgin, contributed equally to this article.

Supporting information for this article is available on the WWW under https://doi.org/10.1002/slct.201900615
Recently, the element distribution, composition and shape control of platinum-based electrocatalyst have been widely studied to reduce platinum usage and improve ORR activity. ${ }^{[6-13]}$ It has been reported that the cost of Pt catalyst is about $50 \%$ in the whole fuel cell stack, ${ }^{[14]}$ which limits its commercial application. Considering that $\mathrm{Pt}$ is scarcely available at high price, low storage and poor durability, ${ }_{1}^{[15]}$ many researchers devote themselves to exploring non-Pt ORR catalysts, such as non-Pt metals ( $\mathrm{Pd}_{1}{ }^{[16,17]} \mathrm{Ag}^{[18]} \mathrm{Fe}^{[19]}$ etc.), metal oxide, ${ }^{[20]}$ perovskite, ${ }^{[21]}$ etc.

In our previous work, we presented good electrochemical performance of faceted $\mathrm{Ag}_{3} \mathrm{PO}_{4}$ towards ORR in alkaline solution according to the design principle of morphology engineering. ${ }^{[22]}$ The charge separation of heterojunction photocatalyst between the $\mathrm{Ag}_{3} \mathrm{PO}_{4}$ and another semiconductor including $\mathrm{BiVO}_{4}{ }^{[23]} \mathrm{AgBr}^{[24]} \mathrm{Cu}_{2} \mathrm{O}^{[25]} \mathrm{TiO}_{2}{ }^{[26]}$ etc, has been widely explored to improve the photochemical activity and stability. Due to the suitable bandgap position and safety, the novel $\mathrm{Ag}_{3} \mathrm{PO}_{4}$ and $\mathrm{Cu}_{2} \mathrm{O}$ composites have attracted much attention and been theoretically investigated for their outstanding electronic and photocatalytic properties. Presently, few researchers studied the ORR performance of the heterojunction between $\mathrm{Ag}_{3} \mathrm{PO}_{4}$ and another semiconductor on electrocatalysts viewed from the point of electronic modification effect.

In this paper, we build a PN junction cross the $\mathrm{Ag}_{3} \mathrm{PO}_{4} / \mathrm{Cu}_{2} \mathrm{O}$ hybrid catalyst to manipulate the electron distribution through the interfacial engineering between $\mathrm{Ag}_{3} \mathrm{PO}_{4}$ and the $\mathrm{Cu}_{2} \mathrm{O}$. Both the experimental results and theoretical calculation show the strong synergistic electronic interactions between $\mathrm{Ag}_{3} \mathrm{PO}_{4}$ and $\mathrm{Cu}_{2} \mathrm{O}$ semiconductors. The hybrid catalysts present better ORR performance than the pure $\mathrm{Ag}_{3} \mathrm{PO}_{4}$ catalyst contributed by the flow of electrons from $\mathrm{Ag}_{3} \mathrm{PO}_{4}$ to $\mathrm{Cu}_{2} \mathrm{O}$. This demonstration plays an important role in the design of hybrid catalysts and has great potential to design alternative non-Pt catalysts as well.

We have successfully synthesized tetrahedron-, rhombic dodecahedron- and cube- $\mathrm{Ag}_{3} \mathrm{PO}_{4}$ with smooth surfaces and sharp corners, which possess corresponding $\{111\},\{110\}$ and $\{100\}$ facets (Figure S1a-c). At the same time, the regular cube$\mathrm{Cu}_{2} \mathrm{O}$ crystals (Figure $\mathrm{S} 1 \mathrm{~d}$ ) were synthesized by the previous report. ${ }^{[27]}$ Three types of $\mathrm{Ag}_{3} \mathrm{PO}_{4}$ with different facets were mixed with $\mathrm{Cu}_{2} \mathrm{O}$ cubes in different mass ratio, respectively. After selecting the compound whose proportion of $\mathrm{Ag}_{3} \mathrm{PO}_{4}$ and 

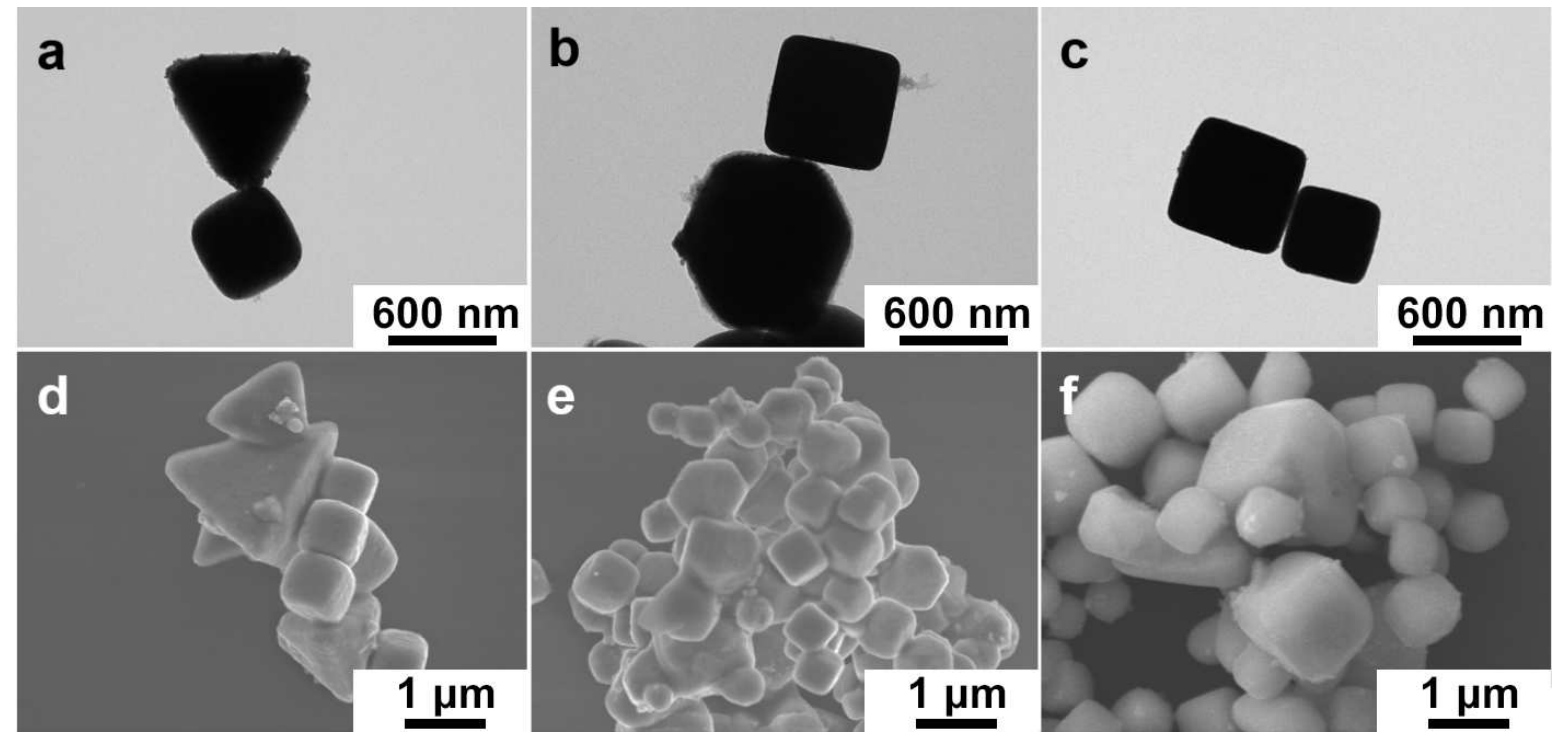

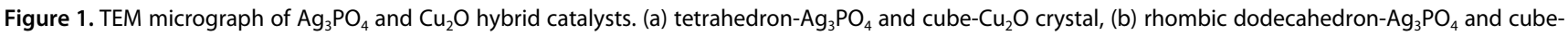
$\mathrm{Cu}_{2} \mathrm{O}$ crystal, (c) cube- $\mathrm{Ag}_{3} \mathrm{PO}_{4}$ and cube- $\mathrm{Cu}_{2} \mathrm{O}$ crystal. SEM micrograph of $\mathrm{Ag}_{3} \mathrm{PO}_{4}$ and $\mathrm{Cu}_{2} \mathrm{O}$ hybrid catalysts: (d) tetrahedron- $\mathrm{Ag}_{3} \mathrm{PO} \mathrm{O}_{4}$ and cube- $\mathrm{Cu}_{2} \mathrm{O}$ crystal, (e) rhombic dodecahedron- $\mathrm{Ag}_{3} \mathrm{PO}_{4}$ and cube- $\mathrm{Cu}_{2} \mathrm{O}$ crystal, $(\mathrm{f})$ cube- $-\mathrm{Ag}_{3} \mathrm{PO}_{4}$ and cube- $\mathrm{Cu}_{2} \mathrm{O}$ crystal.

$\mathrm{Cu}_{2} \mathrm{O}$ is 1 to 0.125 for the SEM and TEM characterizations, we observed that the as-prepared cube- $\mathrm{Cu}_{2} \mathrm{O}$ crystals were coupled closely to three types $\mathrm{Ag}_{3} \mathrm{PO}_{4}$ with $\{111\},\{110\}$ and $\{100\}$ facets, respectively(Figure 1a-c). Their entirely well-distributed mixing was confirmed by the corresponding SEM images (Figure 1d-f). All the X-ray diffraction (XRD) patterns (Figure S2) indicated that the mixture is composed of $\mathrm{Ag}_{3} \mathrm{PO}_{4}$ and $\mathrm{Cu}_{2} \mathrm{O}$, which agrees well with the TEM observation.

The ORR performances of the three $\mathrm{Ag}_{3} \mathrm{PO}_{4} / \mathrm{Cu}_{2} \mathrm{O}$ composites in different proportions were compared to the corresponding pure $\mathrm{Ag}_{3} \mathrm{PO}_{4}$. The ORR polarization curves (Figure $\mathrm{S} 3 \mathrm{a}-\mathrm{c}$ ) show that there are shifts of both onset potential and half-wave potential for these three hybrid $\mathrm{Ag}_{3} \mathrm{PO}_{4} / \mathrm{Cu}_{2} \mathrm{O}$ composites in different proportions compared with the corresponding pure faceted $\mathrm{Ag}_{3} \mathrm{PO}_{4}$ catalyst, which indicates the improved ORR performance after the mixing of $\mathrm{Ag}_{3} \mathrm{PO}_{4}$ particles with $\mathrm{Cu}_{2} \mathrm{O}$ crystals. The enhancement of mass-specific activity in the change of hybrid proportions is summarized in Figure S3d-f and Table S1-3. The optimal mass ratio corresponding to the highest ORR performance of all the hybrid $\mathrm{Ag}_{3} \mathrm{PO}_{4}$ and $\mathrm{Cu}_{2} \mathrm{O}$ system is $1: 0.125$ (Figure $\mathrm{S} 3 \mathrm{~d}-\mathrm{f}$ ) and the ORR polarization curves of each composite with optimal mass ratio are shown in Figure 2a-c, respectively. The corresponding optimal mass activity of tetrahedron-, rhombic dodecahedron- and cube-

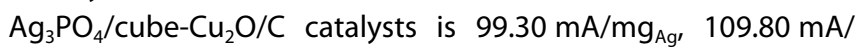
$\mathrm{mg}_{\mathrm{Ag}}, 71.95 \mathrm{~mA} / \mathrm{mg}_{\mathrm{Ag}}$ (Figure $2 \mathrm{~d}$ ), respectively. Compared to the corresponding pure faceted- $\mathrm{Ag}_{3} \mathrm{PO}_{4}$ catalysts with carbon support, the mass-specific activity of the hybrid tetrahedron-

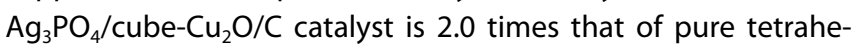
dron- $\mathrm{Ag}_{3} \mathrm{PO}_{4} / \mathrm{C}$ catalyst, 6.4 times that of pure rhombic dodecahedron- $\mathrm{Ag}_{3} \mathrm{PO}_{4} / \mathrm{C}$ catalyst, and 6.5 times that of pure cube- $\mathrm{Ag}_{3} \mathrm{PO}_{4} / \mathrm{C}$ catalyst (Figure $2 \mathrm{~d}$ ). Obviously, hybrid rhombic

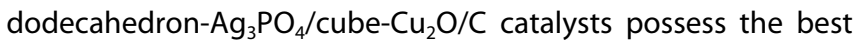

electrochemical performance towards ORR among three hybrid different catalysts.

To further elucidate the relation between $\mathrm{Ag}_{3} \mathrm{PO}_{4}$ and $\mathrm{Cu}_{2} \mathrm{O}$, we conduct a variety of ORR electrocatalytic properties analyses. In our previous work, we have confirmed that rhombic dodecahedron- $\mathrm{Ag}_{3} \mathrm{PO}_{4}$ presents good electrochemically catalytic activity towards ORR under alkaline conditions. ${ }^{[22]}$ Obviously, the cube- $\mathrm{Cu}_{2} \mathrm{O}$ showed poor ORR performance (Figure S4), however, the ORR performance increased sharply when it was mixed with faceted- $\mathrm{Ag}_{3} \mathrm{PO}_{4}$. Briefly, the asprepared rhombic dodecahedron- $\mathrm{Ag}_{3} \mathrm{PO}_{4} /$ cube- $\mathrm{Cu}_{2} \mathrm{O} / \mathrm{C}$ (1: $0.125:$ 4) catalysts show a mass-specific activity of $109.80 \mathrm{~mA} /$ $\mathrm{mg}_{\mathrm{Ag}}$, which is 6.4 times that of a pure rhombic dodecahedron$\mathrm{Ag}_{3} \mathrm{PO}_{4} / \mathrm{C}$ catalyst $\left(17.20 \mathrm{~mA} / \mathrm{mg}_{\mathrm{Ag}}\right)$ (Figure 2$)$. These data suggest that the $\mathrm{Cu}_{2} \mathrm{O}$ does not participate in the ORR directly, and $\mathrm{Ag}_{3} \mathrm{PO}_{4}$ plays the role of an active component. These results support why there is an optimal mass ratio of $\mathrm{Ag}_{3} \mathrm{PO}_{4}$ and $\mathrm{Cu}_{2} \mathrm{O}$, to enhance the activity effectively, the usage of $\mathrm{Cu}_{2} \mathrm{O}$ should be carefully added. It is worthwhile to point out that the poor ORR performance of mixture with too much $\mathrm{Cu}_{2} \mathrm{O}$ could be attributed to poor electrochemical properties of $\mathrm{Cu}_{2} \mathrm{O}$. On the contrary, $\mathrm{Cu}_{2} \mathrm{O}$ plays a limited role if the usage of $\mathrm{Cu}_{2} \mathrm{O}$ is decreased.

To further identify the electronic interactions, XPS analysis of pure rhombic dodecahedron- $\mathrm{Ag}_{3} \mathrm{PO}_{4}$, pure cube- $\mathrm{Cu}_{2} \mathrm{O}$ and the hybrid rhombic dodecahedron- $\mathrm{Ag}_{3} \mathrm{PO}_{4} /$ cube- $\mathrm{Cu}_{2} \mathrm{O}$ was carried out. Figure S6a presents the typical Ag 3d XPS spectra in the hybrid rhombic dodecahedron- $\mathrm{Ag}_{3} \mathrm{PO}_{4} / \mathrm{cube}-\mathrm{Cu}_{2} \mathrm{O}$ and pure rhombic dodecahedron- $\mathrm{Ag}_{3} \mathrm{PO}_{4}$. Compared to pure rhombic dodecahedron- $\mathrm{Ag}_{3} \mathrm{PO}_{4}$, the binding energy of $\mathrm{Ag}$ in the hybrid rhombic dodecahedron- $\mathrm{Ag}_{3} \mathrm{PO}_{4} / \mathrm{cube}^{-} \mathrm{Cu}_{2} \mathrm{O}$ shifts positively. The oxidative state of $\mathrm{Ag}$ indicates that $\mathrm{Ag}$ in hybrid rhombic dodecahedron- $\mathrm{Ag}_{3} \mathrm{PO}_{4} / \mathrm{cube}^{-} \mathrm{Cu}_{2} \mathrm{O}$ loses electrons in 
a

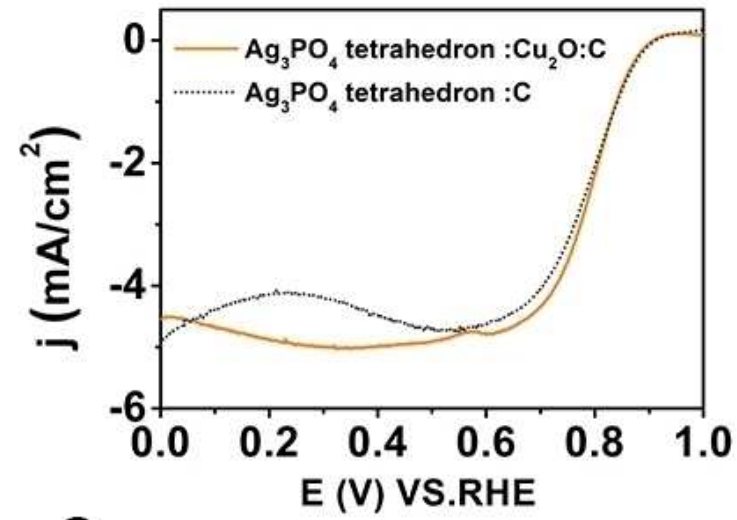

C

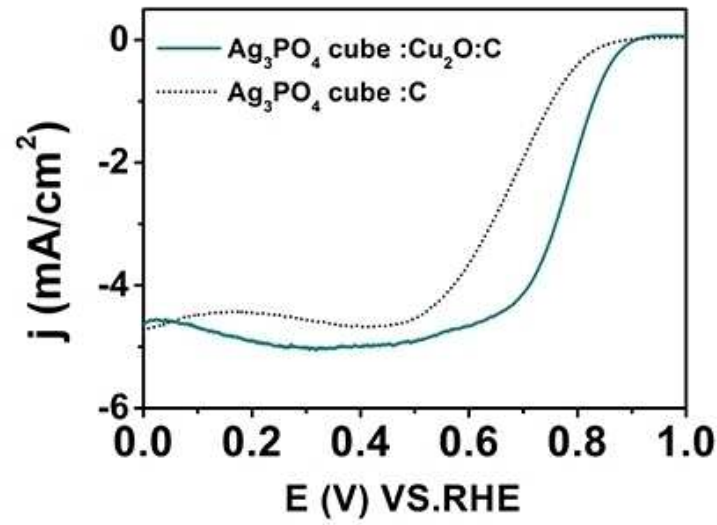

b
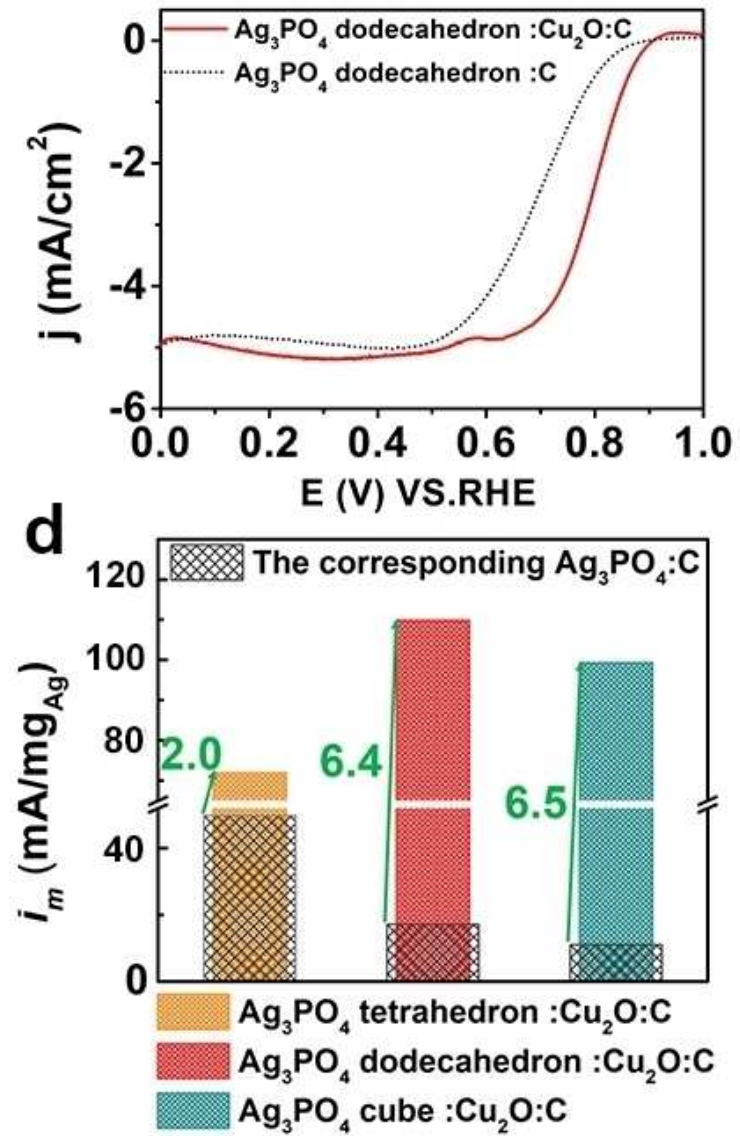

Figure 2. Comparison of electrocatalytic properties with the corresponding pure faceted- $\mathrm{Ag}_{3} \mathrm{PO}_{4}$ : ORR polarization curves of hybrid (a) tetrahedron-; (b) rhombic dodecahedron-; (c) cube- $\mathrm{Ag}_{3} \mathrm{PO}_{4}$ and cube- $\mathrm{Cu}_{2} \mathrm{O}$ supported on carbon catalysts in optimal proportions (1: 0.125: 4); (d) mass-specific activity of hybrid faceted- $\mathrm{Ag}_{3} \mathrm{PO}_{4}$ and cube- $\mathrm{Cu}_{2} \mathrm{O}$ supported on carbon catalysts in optimal proportions (1: 0.125: 4).

the process of mixing with cube- $\mathrm{Cu}_{2} \mathrm{O}$. In addition, Figure $\mathrm{S} 6 \mathrm{~b}$ shows the typical $\mathrm{Cu} 2 \mathrm{p}$ XPS spectra in the hybrid rhombic dodecahedron- $\mathrm{Ag}_{3} \mathrm{PO}_{4} / \mathrm{Cube}^{-} \mathrm{Cu}_{2} \mathrm{O}$ and pure cube- $\mathrm{Cu}_{2} \mathrm{O}$. The negative shift of the $\mathrm{Cu} 2 \mathrm{p} 3 / 2$ peaks shows a more reduced state of $\mathrm{Cu}$ in hybrid rhombic dodecahedron- $\mathrm{Ag}_{3} \mathrm{PO}_{4} /$ cube$\mathrm{Cu}_{2} \mathrm{O}$, indicating that it has obtained more electrons. These results unambiguously demonstrate the electron donation from rhombic dodecahedron- $\mathrm{Ag}_{3} \mathrm{PO}_{4}$ to pure cube- $\mathrm{Cu}_{2} \mathrm{O}$.

Based on the experimental results, we proposed a mechanism for the enhanced ORR electrochemical activity of the different hybrid faceted- $\mathrm{Ag}_{3} \mathrm{PO}_{4} /$ cube- $\mathrm{Cu}_{2} \mathrm{O}$ catalyst. It has been reported that $\mathrm{Ag}_{3} \mathrm{PO}_{4}$ is an n-type semiconductor, ${ }^{[28]}$ while $\mathrm{Cu}_{2} \mathrm{O}$ has been reported as a p-type semiconductor. ${ }^{[29]}$ On the basis of their respective Fermi level, a possible electron transfer behavior between these two semiconductors is drawn in Scheme 1 on the basis of energy band calculations. ${ }^{[30]}$ According to the XPS analysis and semiconductor theory, the electrons transferred from $\mathrm{Ag}_{3} \mathrm{PO}_{4}$ to $\mathrm{Cu}_{2} \mathrm{O}$ at the interface of these two semiconductors, leading to an electron-rich region for $\mathrm{Cu}_{2} \mathrm{O}$ and an electron-deficient region for $\mathrm{Ag}_{3} \mathrm{PO}_{4}$. The DFT calculations on basis of the density of states (DOS) further reveal that the electron transfer (Figure 3f) from $\mathrm{Ag}_{3} \mathrm{PO}_{4}$ to $\mathrm{Cu}_{2} \mathrm{O}$ effectively tunes the $\mathrm{d}$-band structure of $\mathrm{Ag}$ in the hybrid $\mathrm{Ag}_{3} \mathrm{PO}_{4}$ and $\mathrm{Cu}_{2} \mathrm{O}$ system, which results in upshifting $\varepsilon_{\mathrm{d}}$ of $\mathrm{Ag}$ in $\mathrm{Ag}_{3} \mathrm{PO}_{4}(110)$ surface from -2.32 to $-2.26 \mathrm{eV}$ (Figure $3 \mathrm{c}$, e, and g). As clarified by d-band theory, ${ }^{[31,32]}$ this upward shift in $\varepsilon_{d}$ of $\mathrm{Ag}$ in the hybrid $\mathrm{Ag}_{3} \mathrm{PO}_{4} / \mathrm{Cu}_{2} \mathrm{O}$ material will promote catalytic ORR reactions, since the upward shift of the $\mathrm{Ag} d$-band will pull less of the antibonding states below the Fermi level, leading optimal adsorption of intermediates for $\mathrm{Ag}$ in the volcano plot of the oxygen binding energy and thus lead to higher ORR activities. $^{[33]}$

To further support electron transfer theory proposed above, we mixed $\mathrm{Ag}_{3} \mathrm{PO}_{4}$ with another semiconductor $\mathrm{TiO}_{2}$ as a comparison and recorded their ORR polarization curves and calculated mass-specific activity (Figure S5). Under the abovementioned theory, the electron will transfer from $\mathrm{TiO}_{2}$ to $\mathrm{Ag}_{3} \mathrm{PO}_{4}$ (Figure S7) according to energy band structure especially Fermi level of $\mathrm{Ag}_{3} \mathrm{PO}_{4}$ and $\mathrm{TiO}_{2}$. The electron-rich region on the surface of $\mathrm{Ag}_{3} \mathrm{PO}_{4}$ will be no longer able to upshift $\varepsilon_{\mathrm{d}}$ of $\mathrm{Ag}$ (Figure $\mathrm{Ba}$ and $\mathrm{g}$ ). Therefore, the adsorption energy of intermediates will become weaker and then the ORR massspecific activity of hybrid $\mathrm{Ag}_{3} \mathrm{PO}_{4} / \mathrm{TiO}_{2} / \mathrm{C}$ catalyst compared with the pure $\mathrm{Ag}_{3} \mathrm{PO}_{4}$ catalyst will decrease. The experimental 


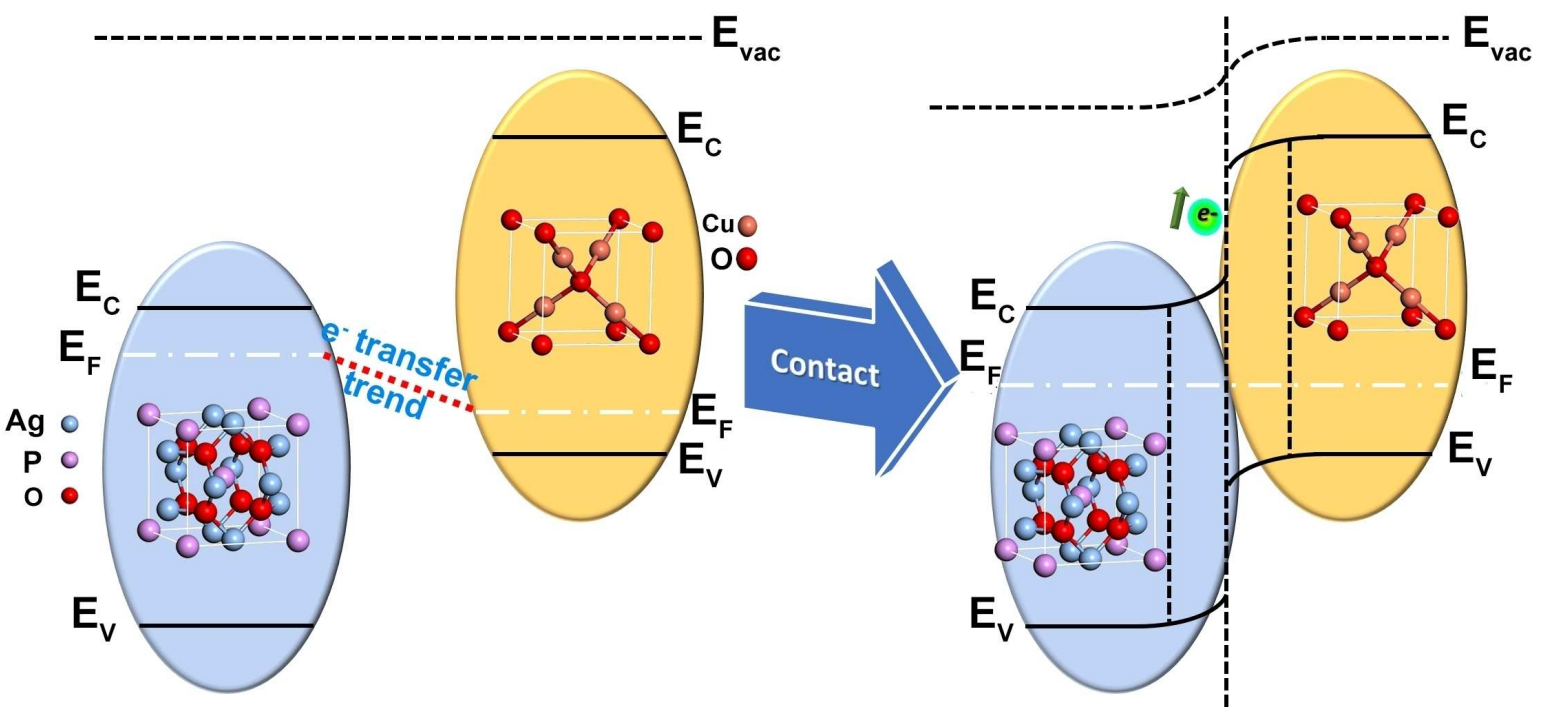

Scheme 1. Electron transfer behaviour at the interface of n-type semiconductor $\mathrm{Ag}_{3} \mathrm{PO}_{4}$ and p-type semiconductor $\mathrm{Cu}_{2} \mathrm{O}$.) a) $\mathrm{E}_{\mathrm{vac}}$ : Vacuum level, $\mathrm{E}_{\mathrm{C}}$ : Conduction band, $\mathrm{E}_{\mathrm{F}}$ : Fermi level, $\mathrm{E}_{\mathrm{V}}$ : Valence band. For $\mathrm{Ag}_{3} \mathrm{PO}_{4}, \mathrm{E}_{\mathrm{C}}=-4.95 \mathrm{eV}, \mathrm{E}_{\mathrm{V}}=-7.35 \mathrm{eV}$ and for $\mathrm{Cu}_{2} \mathrm{O}, \mathrm{E}_{\mathrm{C}}=-3.47 \mathrm{eV}, \mathrm{E}_{\mathrm{V}}=-5.67 \mathrm{eV}$.
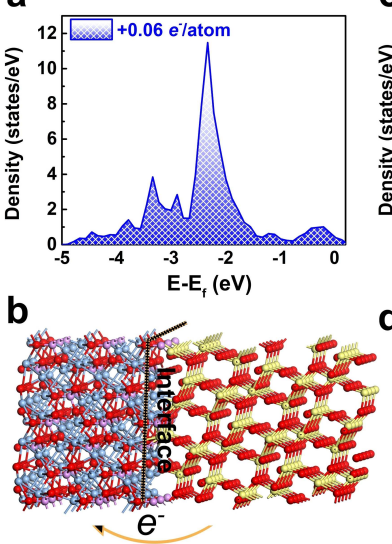

C

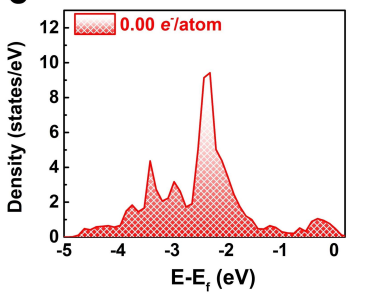

d

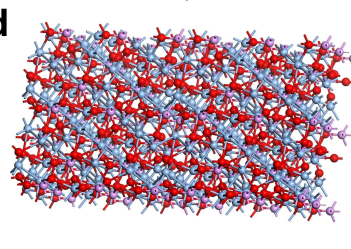

e
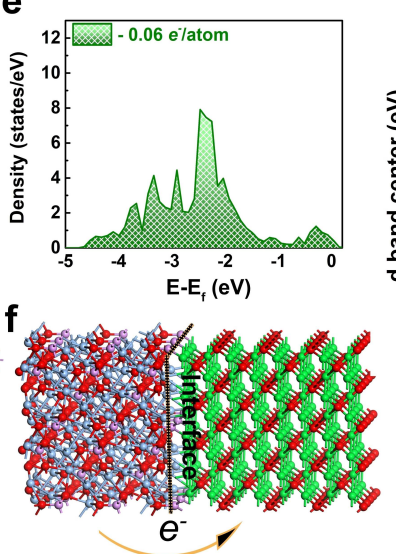

g

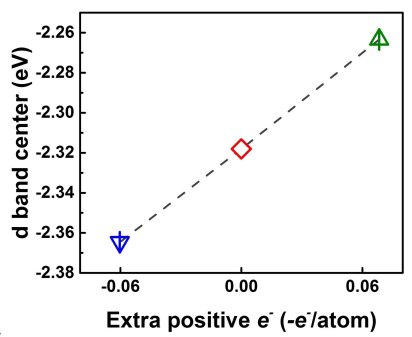

\section{$\mathrm{Ag} \quad \dot{\mathrm{P}} \dot{\mathrm{O}} \stackrel{\circ}{\mathrm{Ti}} \mathrm{Cu}$}

Figure 3. Projected d band density of $\mathrm{Ag}$ in $\mathrm{Ag}_{3} \mathrm{PO}_{4}$ under external charge with a density of (a) +0.06 , (c) 0 , (e)-0.06 eV/atom, the yellow vertical line indicates the corresponding $d$ band center; the corresponding electron transfer schematic diagram at the interface of $(b) \mathrm{Ag}_{3} \mathrm{PO}_{4}$ and $\mathrm{TiO}_{2}$, (d) $\mathrm{pure} \mathrm{Ag}_{3} \mathrm{PO}_{4}$, (f) $\mathrm{Ag}_{3} \mathrm{PO}_{4}$ and $\mathrm{Cu}_{2} \mathrm{O}$; $(\mathrm{g})$ dependence of the $\mathrm{d}$ band center of $\mathrm{Ag}$ in $\mathrm{Ag}_{3} \mathrm{PO}_{4}$ on extra charge.

results fell out as we had expected (Figure S5) that the ORR properties of $\mathrm{Ag}_{3} \mathrm{PO}_{4} / \mathrm{TiO}_{2}$ compound decreased, which have strongly confirmed our theoretical analysis.

In summary, we have developed an electronically coupled $\mathrm{Ag}_{3} \mathrm{PO}_{4} / \mathrm{Cu}_{2} \mathrm{O}$ hybrid electrocatalysts that present a huge improvement in electrocatalytic activity toward ORR as compared with corresponding pure $\mathrm{Ag}_{3} \mathrm{PO}_{4}$ catalysts. It provides a good way to achieve optimal adsorption of intermediates in the volcano plot of the oxygen binding energy and thus high ORR activities by tuning the $\mathrm{d}$-band structure of Ag by utilizing the electron transfer at the interfacial junction of semiconductors. Our work paved a new way for the future efficient application of PEMFCs and exploited a new field in the rational design of non-Pt hybrid catalysts.

\section{Supporting Information Summary}

Experimental procedures, the density functional theory (DFT) calculation method, scanning electron microscope (SEM) images, X-ray diffraction pattern, electrocatalytic properties of various $\mathrm{Ag}_{3} \mathrm{PO}_{4}$ and $\mathrm{Cu}_{2} \mathrm{O}, \mathrm{X}$-ray photoelectron spectroscopy (XPS) and schematic diagram of electron transfer are available in supporting information.

\section{Acknowledgements}

The work is sponsored by the thousand talents program for distinguished young scholars from Chinese government, National Key R\&D Program of China (No. 2017YFB0406000), and National Natural Science Foundation of China (CN) (21875137, 51521004 and 51420105009), and start-up fund (JBW) and the Zhi-Yuan 
Endowed fund (TD) from Shanghai Jiao Tong University. H. Z. thanks the financial support from the Shanghai Sailing Program (16YF1406000) and the computing resources from Shanghai Jiao Tong University Supercomputer Center.

\section{Conflict of Interest}

The authors declare no conflict of interest.

Keywords: Charge Separation Effect - Density Functional Theory · Fuel Cell • Oxygen Reduction Reaction · Semiconductor Heterojunction

[1] F. T. Wagner, B. Lakshmanan, M. F. Mathias, J. Phys. Chem. Lett. 2010, 1, 2204-2219.

[2] Z. Peng, H. Yang, Nano Today 2009, 4, 143-164.

[3] J. Wu, H. Yang, Acc. Chem. Res. 2013, 46, 1848-1857.

[4] M. K. Debe, Nature 2012, 486, 43-51.

[5] H. A. Gasteiger, S. S. Kocha, B. Sompalli, F. T. Wagner, Appl. Catal., B 2005, 56, 9-35.

[6] L. Zhang, L. T. Roling, X. Wang, M. Vara, M. Chi, J. Liu, S.-I. Choi, J. Park, J. A. Herron, Z. Xie, Science 2015, 349, 412-416.

[7] L. Bu, N. Zhang, S. Guo, X. Zhang, J. Li, J. Yao, T. Wu, G. Lu, J. Y. Ma, D. Su, Science 2016, 354, 1410-1414.

[8] C. Chen, Y. Kang, Z. Huo, Z. Zhu, W. Huang, H. L. Xin, J. D. Snyder, D. Li, J. A. Herron, M. Mavrikakis, Science 2014, 343, 1339-1343.

[9] D. Wang, H. L. Xin, R. Hovden, H. Wang, Y. Yu, D. A. Muller, F. J. DiSalvo, H. D. Abruña, Nat. Mater. 2013, 12, 81-87.

[10] T. Bian, H. Zhang, Y. Jiang, C. Jin, J. Wu, H. Yang, D. Yang, Nano Lett. 2015, 15, 7808-7815.

[11] J. Wu, J. Zhang, Z. Peng, S. Yang, F. T. Wagner, H. Yang, J. Am. Chem. Soc 2010, 132, 4984-4985.

[12] J. Wu, A. Gross, H. Yang, Nano lett. 2011, 11, 798-802.

[13] J. Wu, L. Qi, H. You, A. Gross, J. Li, H. Yang, J. Am. Chem. Soc. 2012, 134, 11880-11883.
[14] V. Mazumder, Y. Lee, S. Sun, Adv. Funct. Mater. 2010, 20, 1224-1231.

[15] R. Bashyam, P. Zelenay, Nature 2006, 443, 63-66.

[16] E. Antolini, Energy Environ. Sci. 2009, 2, 915-931.

[17] L. Xiao, L. Zhuang, Y. Liu, J. Lu, J. Am. Chem. Soc. 2008, 131, 602-608.

[18] B. Blizanac, P. N. Ross, N. Marković, J. Phys. Chem. B 2006, 110, 47354741.

[19] M. Lefèvre, E. Proietti, F. Jaouen, J.-P. Dodelet, Science 2009, 324, 71-74.

[20] Y. Y. Liang, Y. G. Li, H. L. Wang, J. G. Zhou, J. Wang, T. Regier, H. J. Dai, Nat. Mater. 2011, 10, 780-786.

[21] J. Suntivich, H. A. Gasteiger, N. Yabuuchi, H. Nakanishi, J. B. Goodenough, Y. Shao-Horn, Nat. Chem. 2011, 3, 546-550.

[22] Y. Qin, F. Li, P. Tu, Y. Ma, W. Chen, F. Shi, Q. Xiang, H. Shan, L. Zhang, P. Tao, C. Song, W. Shang, T. Deng, H. Zhu, J. Wu, RSC Adv. 2018, 8, 53825387.

[23] C. Li, P. Zhang, R. Lv, J. Lu, T. Wang, S. Wang, H. Wang, J. Gong, Small 2013, 9, 3951-3956.

[24] Y. Hou, F. Zuo, Q. Ma, C. Wang, L. Bartels, P. Feng, J. Phys. Chem. C 2012, 11, 20132-20139.

[25] Z. Li, K. Dai, J. Zhang, C. Liang, G. Zhu, Mater. Lett. 2017, 206, 48-51.

[26] S. B. Rawal, S. Do Sung, W. I. Lee, Catal. Commun. 2012, 17, 131-135.

[27] W. C. Huang, L. M. Lyu, Y. C. Yang, M. H. Huang, J. Am. Chem. Soc. 2012, $134,1261-1267$.

[28] Z. J. Yi, J. H. Ye, N. Kikugawa, T. Kako, S. X. Ouyang, H. Stuart-Williams, H. Yang, J. Y. Cao, W. J. Luo, Z. S. Li, Y. Liu, R. L. Withers, Nat. Mater. 2010, 9, 559-564.

[29] H. Raebiger, S. Lany, A. Zunger, Phys Rev B 2007, 76, 045209.

[30] J. T. Li, N. Q. Wu, Catal. Sci. Technol. 2015, 5, 1360-1384.

[31] M. Mavrikakis, B. Hammer, J. K. Nørskov, Phys. Rev. Lett. 1998, 81, 28192822.

[32] J. Greeley, J. K. Nørskov, M. Mavrikakis, Annu. Rev. Phys. Chem. 2002, 53, $319-348$.

[33] J. K. Norskov, J. Rossmeisl, A. Logadottir, L. Lindqvist, J. R. Kitchin, T. Bligaard, H. Jonsson, J. Phys. Chem. B 2004, 108, 17886-17892.

Submitted: February 16, 2019

Accepted: April 25, 2019 